\title{
Cecilia Björkén-Nyberg
}

\section{Når stemmer brydes på nye måder}

\section{Lydbogsindlæsning afklassikere}

His Master's Voice er et varemærke, som de fleste kender til. Logoet med terrieren Nipper, der lytter til lyden fra en grammofontragt, har ikonisk status. Men historien bag Francis Barrauds velkendte billede, sådan som denne fortælles af Jonathan Sterne i The Audible Past (s. 301-303), er muligvis mindre udbredt. Billedet blev malet i begyndelsen af 1890'erne i forbindelse med, at Nippers ejer, Barrauds yngre bror, døde. Dette var inden, grammofonen var blevet lanceret, og oprindeligt var det en fonograf, som blev afbilledet. Senere blev billedet beskåret, så hunden og grammofonen kom mere i fokus, samtidig med at underlaget fremstod mere diffust. I det oprindelige maleri er Nipper og fonografen/grammofonen placeret oven på en blank overflade med afrundede kanter, som mange samtidige betragtere anså for at være kisten med Nippers døde ejer. Nogle forskere har forkastet denne teori, mens andre hævder, at eftersom hunde ofte blev anvendt i repræsentationer af sorg i det victorianske samfund, bør billedet af Nipper ses på denne baggrund.

Den tyske medieforsker Friedrich Kittler er af sidstnævnte mening og mener, at Nipper udviser "[a] vocal-physiological loyalty" over for sin døde ejer (Kittler, 69 , i Sterne, 302). Billedet bliver da udtryk for en auditiv balsameringskultur, som blev etableret i senvictoriansk tid, og som indbefattede fænomenet funereal phonography. For Sterne er det imidlertid uinteressant at slå fast, hvorvidt Nipper faktisk sidder oven på en kiste; han gengiver først og fremmest anekdoten for at illustrere angsten for at miste kontakten med stemmer fra fortiden. Det faktum, at det er en hund og ikke et menneske, som lytter, er i øvrigt også interessant: “...we understand that the important issue is the sound of the voice, not what was said, since dogs are known for heeding the voices of their masters more often than their words" (s. 303). Det er altså frem for alt den vokale, ikke-leksikale dimension af lyden fra grammofonen, som får Nipper til at lytte opmærksomt.

Selvom vore dages lydbogslytning næppe kan beskrives som en form for funereal phonography med lyttere, der er lige så trofaste som hunden Nipper, så findes der i lydbogssammenhængen en lignende fascination, ikke bare af $h v a d$ der bliver sagt 
men også af hvordan det siges. Fænomenet at lytte efter stemmer fra fortiden kan i højeste grad siges at gælde litterære klassikere, som ofte findes i mange lydbogsversioner. I skrivende stund findes der på Audible.uk i uforkortet og ikke-dramatiseret version 29 indlæsninger af Jane Austens Pride and Prejudice, 17 af Charlotte Brontës Jane Eyre og 26 af Oscar Wildes The Picture of Dorian Gray. Desuden findes Charlotte Brontës noget mindre kendte roman Villette i fem indlæsninger, hvoraf den seneste er fra 2019. Det faktum, at mange kanoniske tekster udkommer i stadig nye lydbogsversioner, vidner om et behov for at lytte sig ind på fortiden og forstå periodens miljøer og komplekse sociale relationer gennem stemmefortolkningerne. Antallet af indlæsninger af en given bog kan siges at udgøre et index for værkets stemmesemiotiske kompleksitet. Jo flere indlæsninger, desto større mulighed for at kortlægge en romans sproglige stratificering og dens mangestemmighed eller heteroglossia.

I denne artikel tager jeg udgangspunkt i Mikhail Bakhtins teori om heteroglossia, sådan som denne fremstilles i Discourse in the Novel (1981). Bakhtin slår fast, at "that which makes a novel a novel, that which is responsible for its stylistic uniqueness, is the speaking person and his discourse" (s. 332). Men mens Bakhtin beskriver heteroglossia med henblik på stille læsning i den trykte roman, vil jeg undersøge, hvordan romanens mangestemmighed faktisk kommer til udtryk i et udvalg af lydbogsindlæsninger af de ovenfornævnte klassikere. Eftersom hver indlæsning indebærer en fortolkning, skabes der altid en friktion mellem den trykte tekst og den indlæste version: Hver indlæser har en række valg at foretage i forbindelse med deres oplæsning, men når de har taget disse valg, fastlåser de også teksten i deres specifikke fortolkning. Mit udgangspunkt er, at lydbogslyttere generelt søger mod indlæsninger af ældre kanoniske tekster for gennem indlæseren at få levendegjort de historiske miljøer og sociale relationer, som findes i værkerne, og som kan være svært tilgængelige, når man læser den trykte bog. Der findes imidlertid en risiko for, at indlæsningen tager udgangspunkt i vor egen tids værdier og forhold, når det for eksempel gælder klasse og køn, hvilket enten kan resultere i en eksotiserende forenkling af et historisk miljø eller i en fuldstændig overførsel af vore egne samtidige værdier til værket gennem stemmefortolkningen.

Det er af stor betydning, at man er bevidst om denne problematik, når lydbogsindlæsningerne f.eks. bliver anvendt af studerende, som tilgår ældre klassiske tekster for første gang. Indlæsninger af hele teksten eller af udvalgte uddrag kan også anvendes i undervisningssammenhænge, idet den måde, værkerne fremføres vokalt på, kan give indblik i de sociale relationer i værket. Således kan indlæseren lægge stemme til bestemte dialekter eller på anden vis, gennem tonefald og stemmeføring, markere forhold mellem karakterer, som ellers forbliver uudtalte i den trykte tekst og dermed uden for den moderne læsers rækkevidde. Min diskussion bygger delvis på illustrerende eksempler fra undervisningssituationer, hvor lydbogsoplæsninger bliver anvendt som et metodisk redskab til at problematisere narratologiske aspekter af de givne værker. Jeg vil derudover også referere til kommentarer i lytterfora på den Amazon-ejede distributør af lydbøger, Audible. 


\section{Heteroglossia og indlæserstemmen}

Ifølge Mikhail Bakhtin i Discourse in the Novel er heteroglossia, i betydningen en mangfoldighed af stemmer, et karakteristisk træk ved romanen (s. 300). Eftersom en mængde forskellige sprogformer brydes mod hinanden i romanen, udgør den et mødested for centraliserende, centripetale og decentraliserende, centrifugale kræfter. Det litterære sprog er ét blandt mange, men er i sig selv heteroglot, mangestemmigt, og i stadig dynamisk bevægelse:

6 And this stratification and heteroglossia, once realized, is not only a static invariant of linguistic life, but also what insures its dynamics: stratification and heteroglossia widen and deepen as long as language is alive and developing. Alongside the centripetal forces, the centrifugal forces of language carry on their uninterrupted work; alongside verbalideological centralization and unification, the uninterrupted processes of decentralization and disunification go forward. (s. 272)

Jeg mener, at denne iboende dynamik, som Bakhtin ser som karakteristisk for den trykte roman, fremstår særlig tydeligt, når den får konkret udtryk gennem indlæserens stemme i lydbogsversionen, især eftersom Bakhtin ikke kun betoner betydningen af sprogets lingvistiske aspekter, men også af dets ekspressive dimension (292). Han benytter sig af en musikmetafor for at beskrive den læser, som i sin læseproces ensretter og centraliserer betydningen af den mangestemmige roman: "He transposes a symphonic (orchestrated) theme on to the piano keyboard" (s. 263). For en lydbogsindlæser er arbejdsprocessen omvendt at frigøre alle de stemmer, som allerede findes i den trykte tekst og overføre dem til et partitur, som indeholder alle instrumenternes forskellige klange - og samtidig gøre dette ved hjælp af ét eneste instrument: den menneskelige stemme. På denne baggrund indbyder hver eneste roman til mere en én stemmefortolkning, og hver en sådan fuldført fortolkning bliver for lytteren til en ny mulighed for faktisk, helt konkret, at høre tekstens dynamiske karakter.

Ideen om at frigøre den trykte teksts potentiale gennem den fortolkende stemme kan yderligere belyses gennem Gunther Kress' socialsemiotiske model, sådan som denne præsenteres i Multimodality: A Social Semiotic Approach to Contemporary Communication (2010). Kress påpeger betydningen af at se repræsentation og kommunikation som to forskellige sociale praksisser:

4 Representation focuses on my interest in my engagement with the world and my wish to give material realization to my meanings about that world. Communication focuses on my wish or need to make that representation available to others, in my interaction with them. (s. 49)

Repræsentation beror således på en persons vilje til at efterlade sig et aftryk inden for en specifik historisk kontekst - i denne sammenhæng kunne det handle om Charlotte Brontës måde at repræsentere noget på i sine romaner, i en specifik 1800tals kontekst. Kommunikation handler om at formidle dette aftryk: det kunne f.eks. være den måde, hvorpå Bröntés romaner stemmemæssigt bliver formidlet og fortolket $i$ en moderne lydbog. 
Kress bruger en samling af forhistoriske objekter som eksempel, idet disse ifølge ham kan kommunikere helt forskellige værdier afhængigt af, hvordan de udstilles:

6f The one exhibition seems to want us to see neolithic artefacts as objects of beauty; and to think about the people who made them in that "light". The lighting of the other exhibition encourages us to see the period as dimly visible for us, a "dark age" to us, even though it also displays artefacts of great delicacy and beauty in small glass cases integrated into the tableaux of the rooms. (Kress, 50)

Her har lyssætningen en fortolkende funktion og kommunikerer en vis forestilling om de forhistoriske artefakter og de sociale relationer, som artefakterne materielt set er udtryk for. Lyset arrangeres på en sådan måde, at de påvirker de indbyrdes relationer mellem de forskellige objekter, for eksempel gennem skyggedannelse. Lyset brydes på en unik måde mod hver enkelt genstand og sætter dermed bogstaveligt talt hele samlingen i nyt lys.

Bakhtin taler om netop sådan en brydning - "refraction" - i en sproglig sammenhæng:

Uf If we imagine the intention of [...] a word, that is, its directionality toward the object, in the form of a ray of light, then the living and unrepeatable play of colors and light on the facet of the images that it constructs can be explained as the spectral dispersion of the ray-word. (s. 277)

Han mener, at hvert ord 'brydes' mod andre ord og mod det talende subjekt. En sådan brydning sker også mellem karakterernes individuelle tale i dialog, indslag af semi-litterære (brev og dagbog) samt retoriske (moralske, folisofiske og videnskabelige) genrer og frem for alt mellem alle disse forskellige former for sprog og fortællerens diegetiske stemme:

4f [...] certain aspects of language directly and unmediatedly express (as in poetry) the semantic and expressive intentions of the author, others refract these intentions; the writer of prose does not meld completely with any of these words, but rather accents each of them in a particular way - humorously, ironically, parodically and so forth; yet another group may stand even further from the author's ultimate semantic instantiation still more thoroughly refracting his intentions; and there are, finally, those words that are completely denied any authorial intentions. (s. 299)

Disse forskellige lag af sprog og stemmer findes altså i hver enkelt tekst. De udgør ifølge Bakthin tekstens heteroglossia og skaber dens "elasticitet" (s. 276). En lydbogsoplæser må tage stilling til, hvordan en sådan elasticitet skal fortolkes og kommunikeres. For Kress er repræsentation og kommunikation ofte forbundet med én og samme person. Når det gælder en auditiv fortolkning af en trykt roman, er repræsentation og kommunikationspraksis imidlertid adskilte for så vidt, forfatteren ikke selv indlæser sin tekster - hvilket, af naturlige årsager, ikke er tilfældet i de romaner, som er i fokus her. 


\section{Friktion mellem heterodiegetiske fortællere og dialog}

Jane Austens Pride and Prejudice (1813) indgår som obligatorisk læsning på de fleste uddannelser i Engelsk verden over. Mange studerende kender fortællingen fra de populære filmatiseringer, hvilket ganske vist understøtter undervisningssituationen, men også udgør et problem, eftersom filmene stærkt reducerer den heterodiegetiske fortællerstemme til fordel for de mimetiske dialog-passager. Dette indebærer, at selvom de studerende har en relativ god forståelse for de forskellige karakterers individuelle stemmer og sprogstil, så mangler de ofte viden om forholdet mellem disse stemmer og fortællerstemmen. Bakhtin mener, at romanen som genre fungerer som en slags inskriptionssystem for alle disse stemmer:

6 When heteroglossia enters the novel it becomes subject to an artistic reworking. The social and historical voices populating language, all its words and all its forms, which provide language with its particular concrete conceptualizations, are organized in the novel into a structured stylistic system that expresses the differentiated socio-ideological position of the author amid the heteroglossia of his epoch. (s. 300)

Bakhtin forholder sig til mange af de tidlige engelske romanforfattere, men ikke Jane Austen, til trods for at hendes fiktive verden netop består af den form for netværk af sociale relationer og stemmer, som begrebet heteroglossia dækker over. Det faktum, at Austens romaner har været genstand for omfattende Bakhtinsk analyse, vidner om, at hendes fiktive verden passer godt til studier ud fra dette perspektiv. ${ }^{\mathrm{I}}$

I denne artikel begrænser jeg min diskussion af den mangestemmige - heteroglotte - dimension af Pride and Prejudice til en passage i romanens indledende kapitel. Fortælleren etablerer her sin autoritet gennem en påstand: "It is a truth universally acknowledged, that a single man in possession of a good fortune must be in want of a wife" (Austen, 1). Derefter følger en dialog mellem Mrs og $\mathrm{Mr}$ Bennet, hvor hun er oprørt over, at han tilsyneladende ignorerer det faktum, at en ung, ugift mand lige er flyttet til området. Rachel M. Brownstein hævder, at fortællerens legitimitet, sådan som denne etableres i romanens indledende sætning, nedbrydes og undermineres af Mr og Mrs Bennets samtale, og at disse to karakterer på deres side brydes mod hinanden. Mrs Bennets manglende forståelse for de komplicerede fideikommis-love (love om slægtarv) kan ses som en strategi for at vægre sig mod at underkaste sig og forsvare sig mod et patriarkalsk samfunds love og sædvaner.

Linnea Lundahl mener, at Mrs Bennets feministiske holdning kan forklares ud fra den bakhtinske nar, som forfatteren introducerer "for purposes of 'making strange' the world of conventional pathos" (s. 404). Indsætter man Mrs Bennet i narrens position, giver hun udtryk for en frustration, der kan føres tilbage til konventionelle forhold, som faktisk fremstår urimelige - i dette tilfælde love, som gælder landejendom og arveret. Hun fremstår på én gang dum og indsigtsfuld. Ved at den bakthinske nar introduceres i ræsonnementet, modificeres Brownsteins argument, eftersom narren samtidigt bliver "the object of the author's scorn" (s. 404). Narren får en dobbelt funktion. Den fungerer som redskab for at blotlægge misforhold, men 
samtidig indebærer den for forfatteren en mulighed for at opretholde sin legitimitet i forhold til karakterne gennem en hånlig attitude over for narren. Dermed opstår en speciel form for, hvad Bakthin kalder double-voiced discourse:

Uf Heteroglossia, once incorporated into the novel (whatever the forms for its incorporation), is another's speech in another's language, serving to express authorial intentions but in a refracted way. Such speech constitutes a special type of double-voiced discourse. It serves two speakers at the same time and expresses simultaneously two different intentions: the direct intention of the character who is speaking, and the refracted intention of the author. (s. 324)

En effektiv metode til at 'udsætte' studerende for Austens heteroglossia og doublevoiced discourse på er at lade dem lytte til indlæsninger af visse kapitler eller passager fra romanen. Den passage fra det første kapitel i Pride and Prejudice, som blev diskuteret ovenfor, er særligt interessant til dette formål. I alle versioner som findes på Audible.uk dramatiseres dialogen mellem Mr og Mrs Bennet til en vis grad, men der findes et stort spænd fra en let dramatisering til farce-agtige overdrivelser i fremstillingen af Mrs Bennet. Ved at lytte til et mindre antal, for eksempel tre til fem af sådanne versioner, får de studerende en umiddelbar og konkret forståelse for karakterernes indbyrdes forhold og for forholdet mellem disse og fortælleren. Interessant nok har kun to af de i alt 29 versioner en mandlig fortællerstemme. De kvindelige indlæsere ser sig muligvis nødsaget til at overdrive Mrs Bennets komiske træk for at hendes stemme tydeligere skal bryde af mod den heterodiegetiske fortællers stemme, som også har en kvindes toneleje i indlæsningerne. Hvis ikke de gør det, står kontrasterne mellem de to stemmer ikke tydeligt frem. I nogle af de indlæste versioner forberedes lytteren imidlertid allerede i fortællerens indledende passage på den efterfølgende dialog mellem ægteparret Bennet, idet et let ironisk tonefald sniger sig ind. I en del indlæsninger høres ironien kun i den sætning, som kommer umiddelbart inden dialogen, mens den i andre versioner gennemsyrer hele fortællerens indledende passage. På denne måde undermineres fortællerstemmens autoritet - bevidst eller ubevidst - af indlæseren. Bakhtin påpeger, at "character speech almost always influences authorial speech" (s. 315), og fortsætter:

Uf A character in a novel always has [...] a zone of his own, his own sphere of influence on the authorial context surrounding him, a sphere that extends - and often quite far - beyond the boundaries of the direct discourse allotted to him. (s. 320)

I oplæsninger af teksten træder dette overlap af stemmezoner ikke bare gennem stilistiske egenskaber men også gennem stemmekarakteristik og prosodiske træk, som forstærker dem.

En almindelig reaktion blandt studerende er, at Mrs Bennet i indlæserens fremstilling er en ensidigt komisk figur, specielt eftersom tonelejet er højt, og stemmestyrken påtaget. Det indtryk, som de studerende eventuelt måtte have fået tidligere gennem filmatiseringer af Austens roman, bekræftes således. Med andre ord opfatter de ikke den dobbelte dimension, som forbindelsen til nar-perspektivet medfører. 
Når de studerende får lidt mere viden om de socioøkonomiske vilkår i det tidlige 19. århundrede, kan de imidlertid ofte bringes til at se, at Mrs. Bennets ophidselse skyldes det faktum, at hun har fem døtre, som er helt afhængige af et system, som på alle planer diskriminerer dem. Det er i denne sammenhæng, at lydbogsindlæsningerne bliver et metodisk redskab. Ved at lytte til de forskellige versioner ud fra nyerhvervet viden om køns- og klassemæssige vilkår i perioden, kan den heteroglossia, som ligger i Austens tekst, foldes ud og illustreres gennem de prosodiske og stemmekvalitative karakteristika i de forskellige indlæsninger.

I denne proces er det altså vigtigt, at man bogstaveligt talt hører teksten. Men det handler ikke udelukkende om, at forskellige karakterer lyder forskelligt gennem tonefald og stemmestyrke, men også om forskelle på kompleksitet i de forskellige karakterers tankeprocesser og om, hvordan disse forskelle påvirker deres stemmer og det dialogiske forhold mellem romanpersonerne. I "Bakhtin, Theory of Mind, and Pedagogy: Cognitive Construction of Social Class", nærlæser theory-of-mindforskeren Lisa Zunshine Frances Burneys Evelina (1778) for at vise, at hovedpersonen Evelinas måde at tale på afspejler mere komplekse tankeprocesser end hendes samtalepartner Mr Smiths, og at disse forskelle er af afgørende betydning for at forstå, at de to ikke passer sammen. Zunhines ræsonnement kan overføres til dialogen mellem Mrs og Mr Bennet, hvor det fremgår, at Mrs Bennets replikker har flere indlejrede tankeprocesser end hendes mands:

6f 'Why, my dear, you must know, Mrs Long says that Netherfield is taken by a young man of large fortune from the north of England; that he came down on Monday in a chaise and four to see the place, and was so much delighted with it that he agreed with Mrs Morris immediately; that he is to take possession before Michaelmas, and some of his servants are to be in the house by the end of next week.'

'What is his name?'

'Bingley.'

'Is he married or single?'

'Oh! Single, my dear, to be sure! Single man of large fortune; four or five thousand a-year. What a fine thing for our girls.'

'How so? How can it affect them?'

'My dear Mr Bennet', replied his wife, 'how can you be so tiresome! You must know that I am thinking of his marrying one of them.' (Austen 1, min kursivering)

Som det fremgår af de kursiverede ord, er der mindst tre forskellige mentale niveauer indlejret i Mrs Bennets første replik. Det indledende "you must know [...] England" fungerer som overordnet led, og for hvert af de øvrige findes mindst tre, måske endda fire mentale niveauer repræsenteret. Selvom disse niveauer ikke afspejler Mrs Bennets egne tankeprocesser, så er hun i stand til at gengive dem sådan, som de figurerer i en anden persons bevidsthed. Til sammenligning fremstår $\mathrm{Mr}$ Bennets replikker med de enkle spørgsmål mindre komplekse.

Min hensigt med dette eksempel er ikke at påstå, at Mrs. Bennet er en mere kompleks person end sin mand. Det, jeg derimod vil antyde, er, at den type af kognitive mønstre, som kan synliggøres gennem theory-of-mind-teori, påvirker det dialogiske 
forhold mellem Mrs og Mr Bennet og dermed også den vokale fremstilling af dette forhold. I flere lydbogsversioner synes indlæseren for eksempel at kæmpe med at fremstille de forskellige mentale niveauer i dialogen og samtidig fastholde det høje toneleje, den kraftfulde betoning og stærke volumen, som præger fremførelsen af fortrinsvis korte udråb.

\section{Homodiegetisk fortælling og faren ved empatiens monologisering}

Charlotte Brontës romaner Jane Eyre (1847) og Villette (1853) adskiller sig i flere henseender fra Jane Austens prosa, når det gælder heteroglossia og dialogiske relationer. For det første repræsenteres et bredere socialt lag i Brontës romanverden, og flere forskellige sprog brydes imod hinanden. Studerende, som tilgår Charlotte Brontës romaner i det trykte bogformat, har imidlertid en tendens til at reducere værkernes heteroglossia gennem en centraliserende læsning. Dette indebærer, at de studerende, når de læser den trykte tekst, ikke lader tjenestefolkenes stemmer brydes tilstrækkeligt imod Jane Eyres egen og hendes fostermor Mrs Reeds stemme. Dette skyldes sandsynligvis til dels, at de studerende - og især dem, som ikke har engelsk som modersmål - mangler tilstrækkelig viden om steds- og tidstypiske dialekter eller sociolekter i det engelske sprog. Da disse træk heller ikke er markerede i den trykte tekst, får den stille læseproces en centripetal karakter.

En anden årsag, der kan bidrage til at centralisere læsningen, er det faktum, at Brontës romaner tilhører en litterær kanon. De får derfor en ensidig sproglig indramning, der modsvarer de forventninger, som læsere eventuelt har i forhold til 'finkultur', som som adskiller denne fra mere populærkulturelle komiske og farce-agtige fremførelser. Når man for eksempel lytter til kapitel to, hvor Jane som barn bliver passet af den overtroiske tjenestepige Bessie, introduceres et centrifugalt perspektiv i læsningen. Det bør imidlertid påpeges, at hver stemmefortolkning af en tekst også er et resultat af en individuel og situeret læsning. Indlæseren går til teksten med en egen forforståelse af indholdet og formodentlig også med begrænsede kundskaber om tekstens kompleksitet.

En anden forskel mellem Brontë og Austen er, at Brontës førstepersonsfortæller mangler den autoritet, som Austens tredjepersonsfortæller tilsyneladende har. Kristen Pond påpeger i "Becoming a Stranger to Oneself: Estrangement and Narrative Voice in Jane Eyre", at Jane Eyre, det øjeblik man betragter den som dannelsesroman, ikke primært handler om, at fortællerens stemme bliver stærkere, men om at den mister sin kraft. Undervejs distanceres læseren delvist fra fortællerstemmen. "I refer to these moments in the novel as estrangement scenes to underscore the important distance that opens up between Jane and the reader" (Pond, 205). Disse distancerende scener ser man især i den sidste den af romanen, hvor Jane møder den dybt troende St John, som forsøger at overtale hende til at arbejde sammen med ham som missionær. Vore dages læsere, som er vant til autofiktionstrenden i moderne litteratur, har formodentlig frem til denne del af fortællingen haft relativt let ved at identificere sig med Janes rejse mod større selvstændighed og med hendes forhold til Rochester. Når den kristne tematik sættes i forgrunden, kan læseren have svært ved at bryde denne identifikation og se Jane ud fra andre perspektiver. 
Pond mener, at den nye situation er mere dialogisk i forhold til karakteren, hvilket indebærer, at flere stemmer inkluderes og brydes imod hinanden:

46 Estrangement scenes are important in Jane Eyre, then, not only for how they affect Jane but also for how they affect the reader in terms of sympathy. The kind of sympathy produced in the novel does not necessarily come from a monological viewpoint, as Ablow suggests, but instead emerges out of the distance produced through the estranging effect of multiple voices. In my examination of estrangement in Jane Eyre, therefore, I foreground a different version of sympathy from what is usually identified in nineteenthcentury novels, one that is based on thinking instead of feeling and that requires distance rather than identification. (Pond, 207)

Pond betoner, at det polyvokale indslag påvirker læserens sympati for Jane. Det, som Pond kalder forskellige former for sympati, kan præciseres; læserens stærke følelsesmæssige identifikation med Jane er et udtryk for empati, mens den mere distancerede tankemæssige relation er et spørgsmål om sympati. Denne distinktion mellem empati og sympati stemmer overens med Suzanne Keens definition i Empathy and the Novel, hvor empati defineres som det at føle med og sympati som det at føle for nogen (s. xxi).

En lytterundersøgelse lavet blandt engelskstuderende ved et svensk universitet viser, at en indlæsning af Jane Eyre, der prosodisk kan beskrives som noget hård og distanceret (Nadia May), faktisk stimulerede de studerendes intellektuelle forståelse for fortælleren/hovedpersonens sociale situation i det victorianske England, mens en indlæserstemme af mere intim karakter (Juliet Stevenson) forstærkede det følelsesmæssige i oplæsningen og dermed forstærkede lytterens empatiske forhold til fortælleren/hovedpersonen (Björkén-Nyberg, 83). Den mere intime stemme bidrager også til, at lytteren oplever selv at tage del i fortællingen, mens den mere tilbageholdende stemme begrænser lytteren til bare at være betragter. Men selv om lytterstudiet understøtter forestillingen om, at indlæserens stemmekvalitet og prosodiske profil har betydning for at skabe sympati og empati med fortælleren, så er den af begrænset relevans for Ponds ræsonnement om polivokalitet af den grund, at de forskellige indlæsninger i deres helhed modsvarer enten den ene eller den anden holdning til teksten. Ingen af indlæsningerne kan siges at udtrykke den polyvokalitet, som Pond efterlyser, og som er et resultat af, at fortælleren i visse passager 'forsvinder' for læseren for at lade andre stemmer blive hørt.

Som underviser i litteratur kan man derfor benytte sig af flere forskellige indlæsninger for ikke blot at lade fortællerstemmen brydes mod karakterernes stemmer, men også lade den brydes imod sig selv. En sådan strategi går på tværs af den udvikling, vi ser i dag, mod skabelsen af immersive fiktionsverdner - ikke mindst ved brug af virtual reality-teknik - hvor det frem for alt handler om at skabe fuldstændig identifikation og sætte fokus på oplevelse. En stærk identifikation med fortællere som Jane Eyre, fremført med empati, udfylder den vigtige funktion at åbne en forestillingsverden, sådan som Judith Lander beskriver i Envisioning Literature: Literary Understanding and Literature Instruction (1995). Langer skelner imellem fire forskellige faser i læseprocessen, hvor den første handler om at træde ind i fore- 
stillingsverdenen og den anden om at lade sig omslutte af den fiktive verden. Den tredje fase forstærker læserens identifikation med forestillingsverdenen, mens den fjerde fase forudsætter, at læseren distancerer sig i kraft af en kritisk holdning og med fokus på fortællertekniske greb for at skabe sig en helhedsopfattelse af bogen. En indlæserstemme, som får lytteren til at føle empati, har tendens til at skabe empati gennem teksten som helhed. I Digital Audiobooks: New Media, Users, and Experiences (2016) taler Iben Have og Birgitte Stougaard Pedersen om netop helhedsoplevelse som en affordance: "the overall tone or feeling of the novel appears to be more interconnected as a result of the interpreting voice, intensifying the cohesion of the text” (s. 35). Det kan dog være nødvendigt bevidst at underminere det, som lydbogen således tilbyder i form af en helhedsoplevelse, stærk nærværsfølelse og intimitet, for at lade flere stemmer komme til orde og brydes imod hinanden - det vil sige for, som Pond skriver, at modarbejde, at læseren reducerer teksten til at være monologisk.

Charlotte Brontës Villette har - ligesom Jane Eyre - en førstepersonsfortæller som ser tilbage på sit eget liv, men Lucy Snowe er sværere at identificere sig med på grund af sin tilsyneladende stoiske og lidet indsmigrende holdning over for læseren. Desuden skiller de to romaner sig fra hinanden i flere henseender, som er af interesse ud fra en bakthinsk synsvinkel. Eftersom fortællingen i Villette udspiller sig i den fiktive belgiske by Villette har det franske sprog en fremtrædende plads, og der figurerer også et større antal karakterer end i Jane Eyre. Endvidere er det fænomen, som Bakhtin betegner "incorporated genres" (s. 320), velrepræsenteret i romanen: det vil sige indflettede poetiske og dramatiske tekster samt ikke-kunstneriske retoriske genrer, som dækker religiøse og moralistiske aspekter. At fremføre denne form for heteroglossia i lydbogsversion stiller store krav til lytterens lydhørhed over for tekstens polyvokalitet.

Ud af de fem uforkortede indlæsninger af Villette, som findes på Audible, har fire en saglig tone, som gennem tempo og betoning skaber et indtryk af bestemthed og distance. Dette er især udtalt i Nadia Mays indlæsning. Strengheden i hendes fremførsel er endnu mere udtalt i hendes fortolkning af Villette end af Jane Eyre. Ved at lave en meget kort pause, inden hun udtaler de mange franske udtryk i en let forhøjet tone, som om ordene står i citationstegn, skaber hun indtryk af en modsætning mellem det engelske og det franske sprog. Denne vokale polarisering understreger romanens tematiske polarisering mellem protestantisme og katolicisme som to forskellige måder at se verden på. Mays franske udtale er ikke perfekt, hvilket yderligere forstærker indtrykket af at Lucy Snowe - trods ambitionen om at forbedre sit franske - opretholder en vis distance til alt det, som det franske sprog repræsenterer.

At det franske sprog har så fremtrædende en rolle i Villette udgør et problem for mange lydbogslyttere at dømme efter kommentarer i Audibles forum for lyttere. Samme reaktion har jeg noteret mig hos engelskstuderende. Franske udtryk og dialoger på fransk synes ikke at have nogen værdi for disse lyttere. Men der findes undtagelser. I Audibles lytterforum kommenterer en lytter Mays måde at behandle det franske indslag i romanen på: "If I were reading on my own this would probably be an issue, but because of the way Nadia reads it I was able to catch the meaning of the language without knowing exactly what was said" ("Great perfor- 
mance, boring story"). Denne lytter synes at have sat pris på det vokale aspekt som betydningsbærende i sig selv, og her er stemmen en affordance, som den trykte tekst mangler for en læser uden franskkundskaber. På den anden side, eftersom det er lettere at skimme igennem partier på fransk i en trykt tekst, kan læseren mere eller mindre fravælge disse, mens en lydbogslytter uden teksten foran sig er helt uforberedt, når franske ord og udtryk dukker op. Dette indebærer, at forekomsten af franske ord yderligere distancerer lytteren fra fortælleren og forhindrer en empatisk tilknytning.

En af de fem uforkortede indlæsninger af Villette skiller sig ud fra de øvrige ved en mere intim tiltale. Det er også den version, som har fået flest positive bedømmelser blandt Audibles lyttere. En person skriver: "I had started this book and was not ... sympathetic to the heroine.... Thanks to Mandy Weston's brilliant rendition ... I loved and empathised with Lucy Snow" ("Fascinating and brilliant"). Overordnet sætter lytteren pris på, at Lucy Snow i Westons stemmefortolkning fremstår som en varmere personlighed, som er let at identificere sig med. De fleste lyttere synes til og med at acceptere det franske indslag og lader ikke til at synes, at det forstyrrer helhedsoplevelsen eller nærværsfølelsen. En lytter forsikrer: "Don't be put off by the bits of French in this. They do not detract from the narrative" ("Wonderfully poetic character portraits"). Weston lader den franske udtale følge den overordnede engelske prosodi og skaber dermed ikke samme modsætning som May mellem de to sprog, hvilket har til følge, at de religiøse aspekter heller ikke polariseres i samme udstrækning. Heraf kan man slutte, at selvom Weston fremfører de mange karakterer med deres individuelle sproglige kendetegn, så reduceres den dialogiske dimension alligevel til at blive monologisk.

\section{Den æstetisende romans dialogiske dimensioner}

Som mit ræsonnement omkring Austens og Brontës romaner har vist, giver sproget altid udtryk for en bestemt måde at se verden på, hvilket er fuldstændig i overensstemmelse med Bakhtins dialogiske teori: "A particular language in a novel is always a particular way of viewing the world, one that strives for a social significance" (s. 333). Han mener endvidere, at en sådan ideologisk holdning ofte repræsenteres konkret i den dialogiske diskurs og derfor ikke egner sig til romaner af udpræget æstetiserende karakter, som er præget af leg med ord. Han fortsætter:

Uf Thus when an aesthete undertakes to write a novel, his aestheticism is not revealed in the novel's formal construction, but exclusively in the fact that in the novel there is represented a speaking person who happens to be an ideologue for aestheticism who expresses convictions that then are subjected in the novel to contest. (s. 333)

I denne sammenhæng nævner han Oscar Wildes The Picture of Dorian Gray (1891), en roman der er et udmærket eksempel på "art for art's sake”, og man må formode, at det her er karakteren Lord Henry Wotten, som Bakhtin anser for at fungere som "ideologue for aestheticism". Wildes roman er fortalt i tredje person og indledes med en beskrivelse af kunstneren Basil Hallwards studie i London: 
46 The studio was filled with the rich odour of roses, and when the light summer wind stirred amidst the trees of the garden there came through the open door the heavy scent of the lilac, or the more delicate perfume of the pink-flowering thorn. (s. 1)

I næste passage introduceres Lord Henry Wotton, som ligger på en divan og ryger. I "Narrator/Voice in The Picture of Dorian Gray: A Question of Consistency, Control and Perspective" diskuterer Michael Molino romanens "implied consciousness" og mener, at det er svært at slå fast, om den sanselige miljøbeskrivelse er fortællerens, eller om den er fokaliseret ud fra Lord Henrys perspektiv, og fortælleren dermed forstærker Lord Henrys hedonistiske ideologi. Enten beskriver fortælleren helt enkelt, at Lord Henry befinder sig i studiet, eller også er beskrivelsen filtreret gennem karakteren.

Denne usikkerhed i den trykte tekst, når det gælder forholdet mellem fortællere og fokalisering, reduceres i en oplæst version af romanen. Ud fra et audionarratologisk perspektiv, som betoner forbindelsen mellem lyd og narrativ struktur, er de stemmesemiotiske faktorer betydningsbærende, hvilket indebærer, at fokalisering ikke bare er et spørgsmål om, at nogen ser noget, men også om, hvordan dette perspektiv lyder. I "Audionarratology: Prolegomena to a Research Paradigm" problematiserer Jarmila Mildorf og Till Kinzel den franske narratolog Gérard Genettes brug af begrebet stemme som et hovedsagligt metaforisk begreb:

6f Voices in fiction or other written narrative texts are always mediated or, conversely, are not immediate. This no longer applies once these written narratives have been transposed into aural media, which raises interesting questions regarding sound, voices and music as well as their reception in adaptation. Another area where mediacy turns into immediacy is focalization. (s. 13-14)

Det er i oplæserens fremførelse af Wildes tekst, at stemme bliver konkret og ikkemetaforisk, og det er da oplæseren, som må beslutte, hvordan fortællerens stemme skal forholde sig til Lord Henrys, og om fokaliseringen skal høres.

En anden vigtig afvejning er den vokale relation mellem den fiktive fortælling og Wildes berømte forord, hvor han præsenterer en slags æsteticismens manifest. Eftersom forordet præsenteres direkte i forbindelse med beskrivelsen af Basil Halwards studie og Lord Henrys nærvær dér, kan oplæsningen af forordet have en forstærkende effekt i forhold til den fiktive fortælling. Oplæseren må da ikke bare tage stilling til den heterodiegetiske fortællerstemme og karakterernes fokalisering, men også til forfatterens egen stemme.

Der findes mange vidnesbyrd fra Wildes samtid om hans udtryksfulde stemme og dens musikalske rytme ("The Voice of Oscar Wilde from Beyond the Grave"). Ifølge Max Beerbohm lød den som en blomst, som sprang ud, "uttering itself in leisurely fashion, with every variety of tone", og Walt Whitman noterede hans "English society drawl". I mange år mente man i øvrigt, at Wildes stemme fandtes på en fonograf-indspilning fra år 1900, hvor han læser "The Ballad of Reading Gaol". Længe efter forfatterens $\mathrm{d} ø \mathrm{~d}$ lyttede litteraturelskere med fascination til indspilningen i den tro, at det faktisk var forfatteren selv, som læste op. Wildes søn blev kon- 
sulteret for at afgøre, om den var ægte, og han bekræftede først, at dette var tilfældet for siden at begynde at tvivle, indtil lydeksperter i begyndelsen af 2000-tallet kunne fastslå, at indspilningen var en forfalskning lavet i 1960'erne ("Wilde Recording 'A Fake"'). Denne fascination for dokumentation af forfatterens stemmekvalitet er ikke uvedkommende i en auditiv fremførelse for en roman, hvor en af æsteticismens fortalere, Lord Henry, udtrykkeligt hævdes at have "such a beautiful voice" (Wilde, 17).

I en del indlæsninger af romanen, som findes på Audible, er forordet ikke inkluderet, og i et enkelt tilfælde er det blevet erstattet af musik (Paul Lincoln). I andre versioner læses forordet op i en neutral tone og på en sådan måde, at det fremgår, at det ikke er at betragte som en del af fiktionen. I flere af versionerne kan man notere en lighed i intonation, tempo og tonefald mellem Lord Henrys dialogreplikker og de dele af teksten, som er fokaliserede ud fra hans perspektiv. I en af versionerne er denne overensstemmelse særligt påfaldende, eftersom Wildes "overlæssede" prosastil med mange beskrivende adjektiver fremføres både prosodisk og stemmekvalitativt af indlæseren Steven Crissley. Han læser i et langsomt tempo med tilbageholden stemmestyrke og stærk betoning af visse ord, som har betydning for at forstærke indtrykket af "art for art's sake". Han taler desuden roligt og med stigende intonation - træk som den amerikanske skuespiller Helen Potter interessant nok mente også udmærkede Wildes eget prosodiske mønster ("The Voice of Oscar Wilde from Beyond the Grave"). Frem for alt skaber Crissleys udtrukne vokal- og s-lyde en musikalsk resonans, som både forstærker indtrykket af den semantiske betydning og samtidig eksisterer som en tydelig effekt uafhængigt af den. Denne effekt er især tydelig i længere sammenhængende afsnit, hvor Lord Henrys hedonistiske livsstil beskrives i detaljer, som for eksempel i kapitel 11.

I Crissleys indlæsning smelter stemmen i forordet hos fortælleren og i de fokaliserede partier sammen. I dialoger - og især med Basil Hallward - taler Dorian Gray ofte med en lys stemme, som står i kontrast til Lord Henrys. Dorian Grays stemme synes ikke at have nogen kerne, men defineres i forhold til de øvrige karakterer. I kapitel fire taler han for eksempel med Lady Henry, som siger, at hun holder af Wagners musik, eftersom man sagtens kan tale sammen, mens man lytter til den, uden at udenforstående kan høre, hvad man siger. Dorian svarer da: "I am afraid I don't think so, Lady Henry, I never talk during music - at least, not during good music. If one hears bad music, it is one's duty to drown it in conversation" (s. 45). Lady Henry noterer, at dette er en holdning, som stammer fra hendes mand, hvilket lytteren allerede har kunnet slutte sig til, eftersom Dorian stemmemæssigt her lyder ligesom den kyniske Lord Henry. Desuden begynder de afsnit, der er fokaliserede ud fra Dorians perspektiv, ofte i en lys, drengeagtig tone for siden at antage et mørkere præg, som minder om Lord Henrys stemme.

De forskellige lydbogsversioner håndterer den dialogiske fiktionsverden på forskellig vis, og indlæserne tager forskellige valg i fremførelsen af den heteroglossia, som romanen rummer. Ifølge Bakhtin skaber hver romans særlige mangestemmighed en unik struktur. Som påpeget ovenfor er hver oplæsning en måde at fortolke denne heteroglossia på ud fra forskellige æstetiske og ideologiske overvejelser. I forhold til The Picture of Dorian Gray er forfatterens udtalt æsteticerende holdning en særlig faktor, som bør tages med i betragtning: "The speaking person in the novel is 
always, to one degree or another, an ideologue, and his words are always ideologemes" (Bakhtin, 333). De værdiudsagn, som kommer til udtryk i romanen, kan også blive modsagt igennem stemmefortolkningen. I den lydbogsversion, som har fået mest opmærksomhed i min diskussion af Wildes roman, er dette dog næppe tilfældet. Lord Henrys æsteticisme er her ikke begrænset til dialog-passagerne, men vokaliseres også i de passager, hvor der fortælles i tredje person, samt i forordet, hvis fremførelse er præget af de samme vokale egenskaber, som Lord Henry har, når han taler i dialog. På den måde modsiges hans indflydelse ikke, men bliver snarere bekræftet. Således synes den måde, hvorpå stemmerne brydes mod hinanden, her at bekræfte Lord Henry som ideologue og hans udtalelser som ideologemes. I andre indlæste versioner brydes disse stemmer på andre måder, som i større udstrækning begrænser hans indflydelse og skaber en modvægt til æsteticeringen.

\section{Konklusion}

I indlæsninger af nyudgiven skønlitteraur er vi som moderne læsere lydhøre over for bestemte tonefald eller måder at betone ord på, som på et bestemt tidspunkt altså her i vores nutid - udtrykker en bestemt dimension af dette ord. Dermed bliver vi i stand til at tolke den omgivende tekst derefter. Denne lydhørhed tilegner vi os bare ved at leve i nutiden. Når vi læser skønlitteratur fra historiske epoker, hvor miljøerne kun er nødtørftigt eller slet ikke er dokumenterede i lydoptagelser, rekonstruerer vi de forskellige stemmer i fiktionsverdenen gennem vores egen auditive erindringsbank. Der er en værdi i at læse og forstå en klassiker ud fra hver epokes perspektiv. At en roman opleves som relevant gennem flere generationer er jo også selve definitionen på en klassiker. Ingen indlæsning er derfor 'renere' end nogen anden.

Det faktum, at en klassiker fortsat læses eller lyttes til i nye versioner, er et bevis på dens relevans. Det er også et tegn på, at teksten og dens betydning ikke står stille, men derimod fortsat fungerer som en dynamisk kraft, der kan få ny betydning og relevans i nye historiske perioder. I denne artikel har jeg påvist, hvordan den trykte klassikers dialogiske relationer af sprog og stemmer kan brydes på en mængde nye måder i lydbogsversionerne, gennem indlæserstemmens unikke prosodi og stemmekarakteristika. Den konkrete indlæsning af teksten bliver en katalysator for at opdage nye sociale relationer i teksten. Men jeg har også påvist faren ved at reducere en romans rige netværk af sprog og stemmer - dens heteroglossia - til én monologisk stemme, som blot reflekterer vor egen tids begrænsninger. Det gælder om at høre hinsides Mrs Bennetts sure ophidselse, Jane Eyres intime og empatiskabende fortrolighed og Lucy Snowes karske distance. Det gælder om at værge sig mod effekten af, at forfatterens, fortællerens og fokalisatorens stemme falder sammen i Wildes æstetiserende roman - eller i det mindste gælder det om at forstå, at det netop er sådan, i dette bestemte tilfælde, for at ideen om "art for art's sake" kan komme til udtryk. For at kunne skelne mellem alle disse nuancer i de klassiske tekster må vi, ligesom hunden Nipper, træne vores evne til at lytte, ikke bare efter, hvad der bliver sagt, men også efter, hvordan det bliver sagt. 


\section{Noter}

I For en litteraturoversigt, se Linnea Lundahl, "Laughing at the World: Comedy and Gender in Jane Austen's Pride and Prejudice", speciale, Lunds universitet, 2018.

\section{Litteratur}

Austen, Jane (1979): Pride and Prejudice, 1813, London: Pan Books.

Bakhtin, Mikhail (1981): The Dialogic Imagination: Four Essays by M. M Bakhtin, Michael Holquist (red.), oversat af Caryl Emerson \& Michael Holquist, Austin: University of Texas Press.

Björkén-Nyberg, Cecilia (2020): "Hearing, Seeing, Experiencing: Perspective Taking and Emotional Engagement through the Vocalisation of Jane Eyre, Heart of Darkness and Things Fall Apart," i International Journal of Language Studies, 14.1, s. 63-88.

Brownstein, Rachel M (1988): “Jane Austen: Irony and Authority”, i Last Laughs: Perspectives on Women and Comedy, Regina Barreca (red.), New York: Gordon and Breach, s. 57-70.

Have, Iben og Stougaard Pedersen, Birgitte (2016): Digital Audiobooks: New Media, Users, and Experiences, New York: Routledge.

Keen, Suzanne (2007): Empathy and the Novel, Oxford: Oxford University Press.

Kittler, Friedrich (1999): Gramophone, Film, Typewriter, oversat af Geoffrey Winthrop-Young \& Michael Wutz, Palo Alto: Stanford University Press.

Kress, Gunter (2010): Multimodality: A Social Semiotic Approach to Contemporary Communication, London: Routledge.

Langer, Judith, A. (1995): Envisioning Literature: Literary Understanding and Literature Instruction, New York: Teachers College Press.

Lundahl, Linnea (2018): "Laughing at the World: Comedy and Gender in Jane Austen's Pride and Prejudice", speciale, Lunds universitet, 2018.

Mildorf, Jarmila Mildorf og Till Kinzel (2016): "Audionarratology: Prolegomena to a Reserach Paradigm", i Jarmila Mildorf og Till Kinzel (red.): Audionarratology: Interfaces of Sound and Narrative, Berlin: De Gruyter, s. 1-26.

Molino, Michael R. (1991): "Narrator/Voice in the Picture of Dorian Gray: A Question of Consistency, Control and Perspective", i Journal of Irish Literature, 20.3, s. 6-18.

Pond, Kristen (2016): "Becoming a Stranger to Oneself: Estrangement and Narrative Voice in Jane Eyre", i Brontë Studies, 41.3, s. 205-215.

Sterne, Jonathan (2003): The Audible Past: Cultural Origins of Sound Reproduction, Durham: Duke University Press.

"The Voice of Oscar Wilde from Beyond the Grave" (2019). John H Bartlett, http://johnhbartlett. blogspot.com/2011/03/voice-of-oscar-wilde-from-beyond-grave.html, 15. december 2019, Wilde, Oscar (1981): The Picture of Dorian Gray, Oxford: Oxford University Press.

"WildeRecording 'AFake”" (2000): BBCNews, http://news.bbc.co.uk/2/hi/entertainment/1047178. stm, 29. November 2000.

Zunshine, Lisa (2017). "Bakhtin, Theory of Mind, and Pedagogy: Cognitive Construction of Social Class", i Eighteenth-Century Fiction, 30.1, s. 109-126. 